\title{
ACETYLCHOLINESTERASE ACTIVITY IN THE BRAIN AND MUSCLE OF Cyprinus carpio AND Aristichthys nobilis EXPOSED TO AZIMSULFURON AND METSULFURON-METHYL
}

\author{
JAQUELINE INEU GOLOMBIESKI* \\ ENIO MARCHESAN** \\ GEOVANE BOSCHMANN REIMCHE*** \\ JOELE SCHMITT BAUMART $T^{\star \star \star *}$ \\ JOSEÂNIA SALBEGO***** \\ VÂNIA LUCIA LORO******

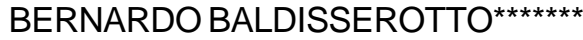

\begin{abstract}
Common carp (Cyprinus carpio) and bighead carp (Aristichthys nobilis) were exposed to azimsulfuron and metsulfuron-methyl (50, 100 and $\left.200 \mathrm{mg} \mathrm{L}^{-1}\right)$. These herbicides are used in rice crop in Southern Brazil. Fishes survived to all tested concentrations of both herbicides and showed normal feeding and swimming behavior. Azimsulfuron inhibits significantly acetylcholinesterase (AChE) in brain and muscle of both species, and metsulfuron-methyl increase AChE activity in brain and inhibits in muscle. The present study showed that azimsulfuron and metsulfuron-methyl did not affect $C$. carpio and $A$. nobilis behaviors (feeding and swimming), but inhibited AChE activity in brain and muscle tissues of these species.
\end{abstract}

KEY-WORDS: HERBICIDES, AChE, CARP; SULFONYLUREA.

Ph.D. em Melhoramento Genético em Arroz, Departamento de Fitotecnia, Universidade Federal de Santa Maria (UFSM), Santa Maria, RS, Brasil (e-mail: jgolombieski@yahoo.com.br).

** Ph.D. em Agronomia, Professor Associado, Departamento de Fitotecnia, UFSM, Santa Maria, RS (e-mail: emarch@ccr.ufsm.br).

*** Engenheiro Agrônomo, Departamento de Defesa Fitossanitária, UFSM, Santa Maria, RS (e-mail: geovane_reimche@yahoo.com.br).

**** Biólogo, Departamento de Biologia, UFSM, Santa Maria, RS (e-mail: jbaumart@gmail.com).

**** Mestre em Bioquímica Toxicológica, Departamento de Química, UFSM, Santa Maria, RS (e-mail: jsalbego@yahoo.com.br).

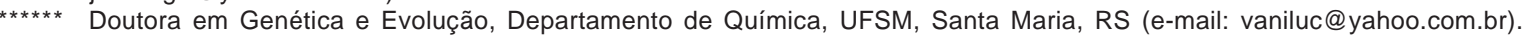

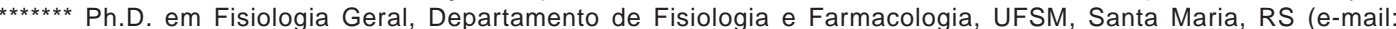
bbaldisserotto@gmail.com). 


\section{INTRODUCTION}

The rice production in Brazil demands the intense use of agrochemicals, mainly herbicides, due to the adopted flooded cultivation, that frequently benefits the emergence of aquatic weed species, which reduces rice growth. Among the rice herbicides registered in Brazil, two of the most used are sulfonylurea, as azimsulfuron [1-(4,6-dimetoxipirimidine2)-3-(1-methyl-4-(2-methyl-2H-tetrazol-5)pyrazol-5-sulfunylurea, and metsulfuron-methyl (methyl 2-[[[(4-metoxi-6-methyl-1,3,5-triazine-2-il)amine]carbonyl]amine] sulfonylbenzoatesulfonylurea) that are selective pre-emergence and post-emergence herbicides, used in pre germinated system, to control broadleaf weeds and some grasses in Southern Brazil (SOSBAI, 2007). The chemical characteristics for azimsulfuron are: water solubility $=1050 \mathrm{mg} \mathrm{L}^{-1}$ at $\mathrm{pH} 7$ and coefficient of partition octane-water $\left(\log \mathrm{K}_{\text {ow }}\right)=-1.37$ at $\mathrm{pH} 7$ for metsulfuron-methyl, water solubility $=2790 \mathrm{mg} \mathrm{l}^{-1}$ at $\mathrm{pH} 7$ and $\log \mathrm{K}_{\mathrm{ow}} 0.018$ at $\mathrm{pH} 7$ (SENSEMAN, 2007). When used in the vicinity of aquatic ecosystems, these pesticides may enter water bodies as a result of spray drift, leaching from the soil and surface runoff during precipitation in concentrations which may exert adverse effects on nontarget organisms inhabiting the area (CHANDRASEKARA and PATHIRATN, 2007). Adverse effects of agrochemicals used in rice culture on biochemical parameters of non-target organisms like fish were previously observed (MIRON et al., 2005; CRESTANI et al., 2007; MORAES et al., 2007; CATTANEO et al., 2008; FONSECA et al., 2008; GOLOMBIESKI et al., 2008; MORAES et al., 2009). Rice-fish culture has been suggested as an alternative for fish and/or rice farmers in South Brazil (SATO, 2002), and the carps Ctenopharyngodon idella, C. carpio, A. nobilis and Hypophthalmichthys molitrix had been the main most frequent species used in this system (SATO, 2002; MARCHEZAN et al., 2006; GOLOMBIESKI et al., 2005; 2007).

Pesticides produce many physiological and biochemical changes in freshwater organisms by influencing the activities of several enzymes (SANCHO et al., 1998). The enzyme acetylcholinesterase plays an essential role in acetylcholine-mediated neurotransmission. It is contained in cholinergic synapses in the central nervous system and in neuromuscular synapses where it rapidly hydrolyzes acetylcholine (DOWNES et al., 2004). Acetylcholinesterase (AChE; EC 3.1.1.7) activity is one of the most frequently used indicators to verify carbamate and organophosphate effects (CHUIKO, 2000; AGUIAR et al., 2004). However, brain AChE activity was inhibited by pesticides or herbicides of another classes as insecticide organochlorine (endosulfan) (DUTTA and ARENDS, 2003) and herbicides isooxazolidinone (clomazone) (MIRON et al., 2005), glycine (glyphosate) (GLUSCZAK et al., 2006) and aryloxialcanoic acid (FONSECA et al., 2008). The inhibition of AChE for herbicides can affect locomotion and equilibrium in exposed organisms and may impair feeding, escape, and reproductive behavior (SAGLIO and TRIJASSE, 1998; BRETAUD, TOUTANT \& SAGLIO, 2000).

Common carp (C. carpio), and bighead carp (A. nobilis) (Cypriniformes) are omnivorous and zooplanktonic species, respectively. This species also could be used in association with fish-rice fields, where herbicides such as azimsulfuron and metsulfuron-methyl are common. Thus, the aim of this study was to investigate the effects of azimsulfuron and metsulfuron-methyl on behavior and AChE activity in brain and muscle tissues of common carp and bighead carp as a possible early indicator of toxicity. 


\section{MATERIAL AND METHODS}

The herbicides used in this study were obtained commercially as follows: metsulfuronmethyl (Ally - 50\% purity), and azimsulfuron (Gulliver - 50\% purity) both from Dupont ${ }^{\circledR}$ (Brazil), and dissolved in water. Acetylthiocholine (AChE, EC 3.1.1.7), DTNB (5,5'dithio-bis 2 nitrobenzoic acid), and bovine serum albumin were purchased from Sigma Chemical Co. (St. Louis, MO, USA). All other reagents used in the experiments were of the highest analytical grade (Aldrich).

Common carp (weight $10.78 \pm 3.48 \mathrm{~g}$ and length $8.64 \pm 0.81 \mathrm{~cm}$ ) and bighead carp (weight $9.42 \pm 0.6 \mathrm{~g}$ and length $8.86 \pm 0.38 \mathrm{~cm}$ ) were obtained from a commercial fish farm near Santa Maria, Rio Grande do Sul State, Brazil, and transported to the Fish Physiology Laboratory of the Universidade Federal de Santa Maria, Santa Maria, Brazil. Fish were acclimated to laboratory conditions for seven days. They were kept in tanks (250 L) and the water was constantly aerated in a static system. Water parameters were measured every day, and were as follow: temperature $17.8 \pm 0.16^{\circ} \mathrm{C}, \mathrm{pH} 7.6 \pm 0.02$ units, dissolved oxygen $5.5 \pm 0.16 \mathrm{mg} \mathrm{L}^{-1}$, non-ionized ammonia $0.02 \pm 0.002 \mathrm{mg} \mathrm{L}^{-1}$, nitrite $0.03 \pm 0.014 \mathrm{mg} \mathrm{L}^{-1}$, alkalinity $45 \pm 3.25 \mathrm{mg} \mathrm{L}^{-1} \mathrm{CaCO}_{3}$ and hardness $21 \pm 3.56 \mathrm{mg} \mathrm{L}^{-1} \mathrm{CaCO}_{3}$. During acclimation, fish were fed once a day with commercial fish pellets (42\% crude protein, Supra, Brazil). Sewage and pellet leavings were removed every other day by suction.

After the acclimation period, groups of $10 \mathrm{fish} / \mathrm{box}$ (36 L glass box) (triplicate) were exposed for 96h, as usually performed in acute experiments (MIRON et al., 2008), to different nominal concentrations of azimsulfuron and metsulfuron-methyl $\left(\mathrm{mg} \mathrm{L}^{-1}\right): 50,100$ e 200 . Control fish were maintained in the same condition, but in water without the herbicide. Herbicides were added to the water only at the beginning of the experiment. During the experimental period fish were fed every day with commercial feed (44\% crude protein) (Purina Brazil). Feces and pellet residues were removed daily by suction removing the minimal water quantity.

Water $\mathrm{pH}$ was measured electrometrically (pHmeter Schott Handylab 1), water temperature and dissolved oxygen with an oxygen meter (Oximeter Oakton) and water hardness and alkalinity according to APHA (1992). Total ammonia and nitrite were determined by kits (Alfatecnoquímica, Florianópolis, Brazil). Throughout experiment swimming activity (normal, erratic swimming, lethargy, immobility) and feeding behavior (feeding or not) were observed for $30 \mathrm{~min}$ at the time of feeding, registered, and compared to control. At the end of exposure period (96h), six fish were randomly chosen from each box and killed by punching the spinal cord behind the opercula, placed in ice and, tissues (brain and muscle) were removed on ice, frozen in liquid nitrogen and then stored at $-20^{\circ} \mathrm{C}$ until $\mathrm{AChE}$ assay.

Enzyme activity was determined in fishes exposed to all tested concentrations of both herbicides: 50,100 and $200 \mathrm{mg} \mathrm{L}^{-1}$. Brain and muscle tissues were weighed and homogenized in $150 \mathrm{mM} \mathrm{NaCl}\left(15 \mathrm{mg} \mathrm{mL}^{-1}\right)$ using a Potter-Elvejhem glass/Teflon homogenizer. The homogenates were centrifuged for $15 \mathrm{~min}$ at $3000 \mathrm{~g}$ at $5^{\circ} \mathrm{C}$ and the supernatant was used as the enzyme source. AChE activity was measured as described by ELLMAN, COURTNEY \& ANDRES (1961) and modified by MIRON et al. (2005). Aliquots of supernatant (50-100 $\mu \mathrm{L}$ ) (brain and muscle, respectively) were incubated at $25^{\circ} \mathrm{C}$ for 2 min with $0.1 \mathrm{M}$ phosphate buffer, $\mathrm{pH} 7.5 ; 1 \mathrm{mM}$ DTNB as chromogen. After $2 \mathrm{~min}$, the reaction was initiated by the addition of acethylthiocholine $(0.08 \mathrm{M})$ as substrate for the reaction mixture. The final volume was $2.0 \mathrm{~mL}$. Absorbances were determined at $412 \mathrm{~nm}$ during $2 \mathrm{~min}$. Enzyme activity was expressed as $\mu \mathrm{mol}$ of acethylthiocholine (AcSCh) hydrolyzed per min per gram of protein.

The values for common carp were for azimsulfuron (minimum and maximum): dissolved oxygen 6.1-6.8 $\mathrm{mg} \mathrm{L}^{-1}$, temperature $17.2-18.4^{\circ} \mathrm{C}, \mathrm{pH} 7.6-7.9$, alkalinity 
32-46 mg L-1 $\mathrm{CaCO}_{3}$, hardness 24-32 $\mathrm{mg} \mathrm{L}^{-1} \mathrm{CaCO}_{3}$, total ammonia 0.5-3 mg L-1, nonionized ammonia 0.01-0.02 $\mathrm{mg} \mathrm{L}^{-1}$, and nitrite 0-0.05 $\mathrm{mg} \mathrm{L}^{-1}$; metsulfuron-methyl: dissolved oxygen 6.8-7.4 $\mathrm{mg} \mathrm{L}^{-1}$, temperature $15-16.7^{\circ} \mathrm{C}, \mathrm{pH} 7.4-7.8$, alkalinity $34-49 \mathrm{mg} \mathrm{L}^{-1} \mathrm{CaCO}_{3}$, hardness $20-32 \mathrm{mg} \mathrm{L}^{-1} \mathrm{CaCO}_{3}$, total ammonia 0.5-2 $\mathrm{mg} \mathrm{L}^{-1}$, non-ionized ammonia 0.007-0.018 $\mathrm{mg} \mathrm{L}^{-1}$, and nitrite 0.02-0.05 $\mathrm{mg} \mathrm{L}^{-1}$.

For bighead carp the parameters were: azimsulfuron: dissolved oxygen 6.1-7.1 $\mathrm{mg} \mathrm{L}^{-1}$, temperature $16.6-20.1^{\circ} \mathrm{C}$, pH 7.5-7.9, alkalinity 24-40 $\mathrm{mg} \mathrm{L}^{-1} \mathrm{CaCO}_{3}$, hardness $24-36 \mathrm{mg}$ $\mathrm{L}^{-1} \mathrm{CaCO}_{3}$, total ammonia 0.5-2 $\mathrm{mg} \mathrm{L}^{-1}$, non-ionized ammonia $0.011-0.038 \mathrm{mg} \mathrm{L}^{-1}$ and nitrite 0.03-0.05 mg L-1; metsulfuron-methyl: dissolved oxygen $6.0-6.5 \mathrm{mg} \mathrm{L}^{-1}$, temperature $19.4-20.7^{\circ} \mathrm{C}$, $\mathrm{pH}$ 7.7-8.0, alkalinity 34-39 mg L-1 $\mathrm{CaCO}_{3}$, hardness $20-24 \mathrm{mg} \mathrm{L}^{-1} \mathrm{CaCO}_{3}$, total ammonia 0.5-1 $\mathrm{mg} \mathrm{L}^{-1}$, non-ionized ammonia 0.024-0.038 $\mathrm{mg} \mathrm{L}^{-1}$, and nitrite 0-0.02 $\mathrm{mg} \mathrm{l}^{\mathrm{l}^{-1}}$.

Statistical analyses were performed using one-way analysis of variance (ANOVA). Means were compared by Tukey test and expressed as mean \pm standard error $(n=6)$ (BANZATO and KRONCA, 1995). Differences were considered to be significant at a probability level of $P<0.05$ between treatments and controls.

\section{RESULTS}

All common and bighead carps fingerlings exposed to azimsulfuron and metsulfuronmethyl survived even at the highest concentration used (200 $\left.\mathrm{mg} \mathrm{L}^{-1}\right)$, and showed normal feeding and swimming behavior at all concentrations tested (Table 1).

\section{TABLE 1 - EFFECT OF DIFFERENT CONCENTRATIONS OF AZIMSULFURON AND METSULFURON-METHYL ON FEEDING AND SWIMMING BEHAVIORS, AND BRAIN AND MUSCLE AChE ACTIVITY IN CARPS}

\begin{tabular}{ccccc}
\hline $\begin{array}{c}\text { Herbicides/ } \\
\text { species }\end{array}$ & $\begin{array}{c}\text { Feeding } \\
\text { behavior }\end{array}$ & $\begin{array}{c}\text { Swimming } \\
\text { behavior }\end{array}$ & $\begin{array}{c}\text { Brain AChE activity (\% } \\
\text { of control) } \\
\text { Common Carp }\end{array}$ & $\begin{array}{c}\text { Muscle AChEactivity (\% } \\
\text { of control) }\end{array}$ \\
\hline Azimsulfuron & & & & 100 \\
\hline Control & Feeding & Normal & 100 & 61 \\
$50 \mathrm{mg} \mathrm{L}^{-1}$ & Feeding & Normal & 55 & 40 \\
$100 \mathrm{mg} \mathrm{L}^{-1}$ & Feeding & Normal & 73 & 43 \\
$200 \mathrm{mg} \mathrm{L}^{-1}$ & Feeding & Normal & 66 & 100 \\
\hline Metsulfuron & & & & 79 \\
\hline Control & Feeding & Normal & 100 & 31 \\
$50 \mathrm{mg} \mathrm{L}^{-1}$ & Feeding & Normal & 131 & 57 \\
$100 \mathrm{mg} \mathrm{L}^{-1}$ & Feeding & Normal & 126 & 100 \\
$200 \mathrm{mg} \mathrm{L}^{-1}$ & Feeding & Normal & 136 & 45 \\
\hline & & & Bighead carp & 51 \\
\hline Azimsulfuron & & & 100 & 35 \\
\hline Control & Feeding & Normal & 44 & 100 \\
$50 \mathrm{mg} \mathrm{L}^{-1}$ & Feeding & Normal & 44 & 47 \\
$100 \mathrm{mg} \mathrm{L}^{-1}$ & Feeding & Normal & 23 & 24 \\
$200 \mathrm{mg} \mathrm{L}^{-1}$ & Feeding & Normal & & 27 \\
\hline Metsulfuron & & & 100 & \\
\hline Control & Feeding & Normal & 121 & \\
$50 \mathrm{mg} \mathrm{L}^{-1}$ & Feeding & Normal & 135 & \\
$100 \mathrm{mg} \mathrm{L}^{-1}$ & Feeding & Normal & 145 & \\
$200 \mathrm{mg} \mathrm{L}^{-1}$ & Feeding & Normal & &
\end{tabular}


Brain of unexposed control fish showed higher specific AChE activity than muscle for azimsulfuron (Figure 1 - A); control: common carp 16.47 against 8.02 and bighead carp 15.6 against $8.02 \mu \mathrm{mol} / \mathrm{min} / \mathrm{g}$ protein, respectively. After azimsulfuron exposure, AChE activity was significantly lower $(P<0.05)$ at all concentrations tested (Figure 1- A and B) in both tissues of the two species, after $96 \mathrm{~h}$ exposure to azimsulfuron. Azimsulfuron inhibition reached maximum of $45 \%$ in the brain and $60 \%$ in the muscle of common carp and $77 \%$ in the brain and $65 \%$ in the muscle of bighead carp (Table 1 ).

\section{FIGURE 1 - EFFECTS ON THE AChE ACTIVITY IN BRAIN AND MUSCLE OF CARPS (Cyprinus carpio AND Aristichthys nobilis) AFTER 96h EXPOSURE FOR AZIMSULFURON (A) AND METSULFURON-METHYL (B)}

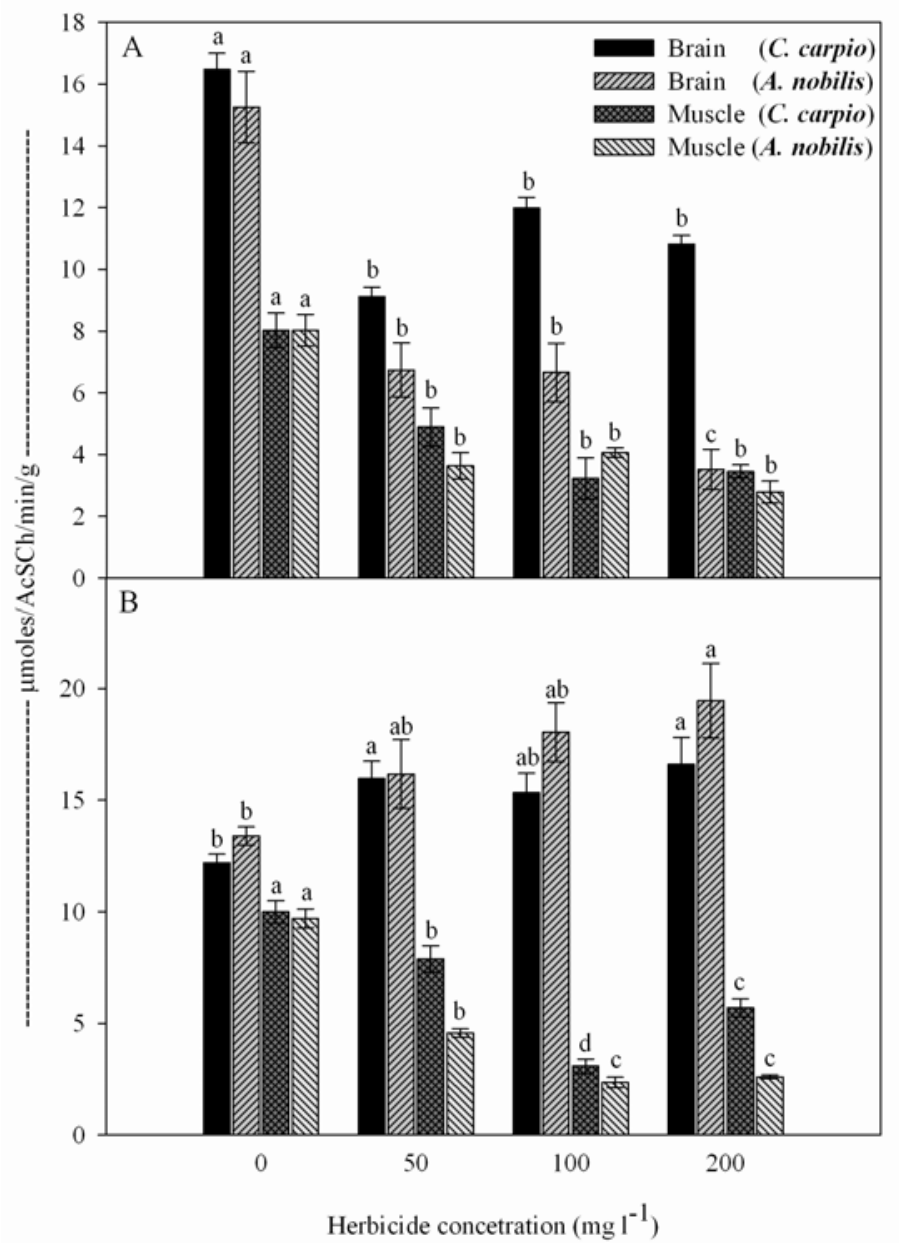

Values are mean \pm sem $(N=6)$. Data are expressed as $\mu \mathrm{Mol} / \mathrm{acsch} / \mathrm{min} / \mathrm{g}$ protein. Different letters indicate significant difference of AChE activity considering the tissue analyzed in each fish species $(P<0.05)$.

For metsulfuron-methyl (Figure 1-B) brain AChE activity was higher than muscle for two carps species in control treatment; common carp 12.2 against 9.99 and bighead carp 13.4 and $9.7 \mu \mathrm{mol} / \mathrm{min} / \mathrm{g}$ protein. Maximum metsulfuron-methyl inhibition in the muscle common carp and bighead carp was 69 and 76\%, respectively.

Conversely, exposure to all metsulfuron-methyl concentrations tested for $96 \mathrm{~h}$ significantly increased AChE activity in the brain of both species (Figure 1 - B) (common carp 31-36\% and 
bighead carp 21-45\% as compared to control values). However, for muscle tissue significantly decreased AChE activity to all metsulfuron-methyl concentrations for two carps.

\section{DISCUSSION}

In Southern Brazil azimsulfuron and metsulfuron-methyl are applied to rice crop at 0.005 and $0.002 \mathrm{mg} \mathrm{L}^{-1}$, respectively (SOSBAI, 2007). In the current study, no fish mortality or changes in feeding and swimming behavior was observed even in the highest concentration (200 $\left.\mathrm{mg} \mathrm{L}^{-1}\right)$ for both herbicides, what represents 40.000 and 100.000 times higher than the concentrations of rice fields water. Therefore, in carps these parameters can not be used as indicators of water contamination by these herbicides. RESGALLA et al. (2002) found for common carp fingerlings $(2-8 \mathrm{~cm}) 96 \mathrm{~h} \mathrm{LC}_{50} 26 \mathrm{mg} \mathrm{L}^{-1}$ for metsulfuron-methyl (concentration tested 1-64 mg L-1). SENSEMAN (2007) reported carps 96h LC $\mathrm{L}_{50}$ for azimsulfuron $>1000 \mathrm{mg} \mathrm{L}^{-1}$ and for rainbow trout $492 \mathrm{mg} \mathrm{L}^{-1}$, and the $96-\mathrm{h} \mathrm{LC}_{50}$ was $150 \mathrm{mg} \mathrm{L}^{-1}$ for metsulfuron-methyl.

The herbicides can affect various types of behavior in fish, directly as well as indirectly by altering the chemical perception of natural substances of ecoethological importance (SAGLIO and TRIJASSE, 1998). The results obtained for carps exposed to azimsulfuron and metsulfuron-methyl showed feeding and normal swimming behavior at all concentrations. Silver catfish (Rhamdia quelen) fingerlings exposure to metsulfuron-methyl (200 to $1200 \mathrm{mg} \mathrm{L}^{-1}$ ) showed normal feeding behavior but burst swimming reactions at all tested concentration (400, 800 and $1200 \mathrm{mg} \mathrm{L}^{-1}$ ) (MIRON et al. 2004). This change of swimming activity was also observed in goldfish exposed of the 0.001 to $10 \mathrm{mg} \mathrm{L}^{-1}$ nicosulfuron (sulfunylurea) (SAGLIO et al., 2001).

The activity of AChE enzyme is extremely important for many physiological functions, such as fast locomotion, predator evasion, and orientation toward food. When AChE activity decreases, $\mathrm{ACh}$ is not broken and accumulates within synapses which therefore cannot function in a normal way (DUTTA and AREND, 2003).

The results of the present study showed that, in unexposed fish brain to azimsulfuron, AChE-specific activity was two-fold higher than that in muscle tissue. Higher brain AChE activity was also observed in channel catfish (Ictalurus punctatus) after exposure to organophoshorus compounds (STRAUS and CHAMBERS, 1995). The AChE activity in juvenile goldfish (Carassius auratus) exposed to nicosulfuron herbicide (sulfunylurea) was higher in brain and did not induce effect in the muscle (BRETAUD, TOUTANT \& SAGLIO, 2000). Labeo rohita exposure to cypermetrin (organophosphorus) (DAS and MUKHERJEE, 2003) had significantly decreased in brain AChE activity in 45 days.

The AChE inhibition observed in fish exposed to azimsulfuron, leads to an accumulation of acetylcholine, causing over-stimulation of the receptors. According to FERNÁNDEZ-VEGA et al. (1999; 2002) and MIRON et al. (2005) AChE inhibition in brain and muscle produces adverse effects in movement because AChE participates in neural and neuromuscular transmissions. However, AChE activity in the brain of carps exposed to metsulfuron-methyl was higher than in control fish, but no change on feeding and swimming behaviors, with active carps until 96h exposition. This study is in agreement with MIRON et al. (2005) that obtained the same results for silver catfish (Rhamdia quelen) exposed to several metsulfuronmethyl concentrations (400, 800 and $\left.1200 \mathrm{mg} \mathrm{L}^{-1}\right)$.

The activation observed in AChE activity after exposure to metsulfuron-methyl could represent an increase in the hydrolysis of the neurotransmitter acetylcholine, with a 
consequent decreased activation of nicotinic and muscarinic receptors. Thus, activation or inhibition of AChE can influence the process of cholinergic neurotransmission and promote undesirable effects. Therefore, azimsulfuron and metsulfuron-methyl appears safe for common and bighead carps.

\section{CONCLUSION}

The present study showed that azimsulfuron and metsulfuron-methyl did not affect C. carpio and A. nobilis behavior, but inhibited AChE activity in brain and muscle tissues of these species.

\section{RESUMO}

\section{ATIVIDADE DA ACETILCOLINESTERASE EM CÉREBRO E MÚSCULO DE CARPAS Cyprinus carpio E} Aristichthys nobilis EXPOSTAS A AZIMSULFURON E METSULFURON-METIL

Alevinos de carpa húngara (Cyprinus carpio) e carpa cabeça grande (Aristichthys nobilis) foram expostas a azimsulfuron e metsulfuron-metil $\left(50,100\right.$ and $\left.200 \mathrm{mg} \mathrm{L}^{-1}\right)$, herbicidas utilizados em lavouras de arroz no Sul do Brasil. Os peixes sobreviveram a todas as concentrações testadas de ambos os herbicidas e mostraram comportamento alimentar e natatório normal. Azimsulfuron inibiu significativamente a enzima acetilcolinesterase (AChE) em cérebro e músculo de ambas as espécies e metsulfuron-metil aumentou a atividade da AChE no cérebro e a inibiu em músculo. O presente estudo mostrou que azimsulfuron e metsulfuron-metil não afetam os comportamentos (alimentar e natatório) de C. carpio e A. nobilis, mas inibiram a atividade da AChE em tecido cerebral e muscular dessas espécies.

PALAVRAS-CHAVE: HERBICIDAS; AChE; CARPAS; SULFUNILURÉIA.

\section{REFERENCES}

1 AGUIAR, L.H. et al. Metabolical effects of folidol 600 on the neotropical freshwater fish matrinxã , Brycon cephalus. Environmental Research, v. 95, p. 224-230, 2004.

2 APHA. American Public Health Association. Standard methods for examination of water and wastewater. $18^{\text {th }}$ ed. Sprinfield, 1992. $1155 \mathrm{p}$.

3 BANZATO, D. A.; KRONCA, S. N. Experimentação agrícola. 3. ed. Jaboticabal: FUNEP, 1995. 247 p.

4 BRETAUD, S.; TOUTANT, J.P.; SAGLIO, P. Effects of carbofuran, diuron, and nicosulfuron on acetylcholinesterase activity in Goldfish (Carassius auratus). Ecotoxicology and Environmental Safety, v. 47, p.117-124, 2000.

5 CATTANEO, R. et al. Metabolic and histological parameters of silver catfish (Rhamdia quelen) exposed to commercial formulation of 2,4-dichlorophenoxiacetic acid (2,4-D). Pesticide Biochemistry and Physiology, v. 92, p. 133-137, 2008.

6 CHANDRASEKARA, L.W.H.U.; PATHIRATNE, A. Body size-related differences in the inhibition of brain acetylcholinesterase activity in juvenile Nile tilapia (Oreochromis niloticus) by chlorpyrifos and carbosulfan. Ecotoxicology and Environmental Safety, v. 67, p.109-119, 2007.

7 CHUIKO, G.M. Comparative study of acetylcholinesterase and butyrilcholinesterase in brain and serum of several freshwater fish: specific activities and in vitro inhibition by DDVP, an organophosphorus pesticide. Comparative Biochemistry and Physiology Part C, v.127, p. 233-242, 2000.

8 CRESTANI, M.; MENEZES, C.; GLUSCZAK, L.; MIRON, D. S.; SPANEVELLO, R.; SILVEIRA, A.; GONÇALVES, F.F.; ZANELLA, R.; LORO, V. L. Effect of clomazone herbicide on biochemical and histological aspects of silver catfish (Rhamdia quelen) and recovery pattern. Chemosphere, v. 67, p. 2305-2311, 2007. 
9 DAS, B.K.; MUKHERJEE, S.C. Toxicity of cypermethrin in Labeo rohita fingerlings: biochemical, enzymatic and haematological consequences. Comparative Biochemistry and Physiology Part C, v. 134, p. 109121, 2003.

10 DOWNES, G.B.; GRANATO, M. Acetylcholinesterase function is dispensable for sensory neurite growth but is critical for neuromuscular synapse stability. Developmental Biology, v. 270, p. 232-245, 2004.

11 DUTTA, H.M.; ARENDS, D.A. Effects of endosulfan on brain acetylcholinesterase activity in juvenile bluegill sunfish. Environmental Research, v. 91, p. 157-162, 2003.

12 ELLMAN, G.L.; COURTNEY, K.D.; ANDRES JR, V. A new and rapid colorimetric determination of acetylcholinesterase activity. Comparative Biochemistry and Physiology Part C, v. 7, p. 88-95, 1961.

13 FERNÁNDEZ-VEGA, C. et al. Thiobencarb toxicity and plasma AChE inhibition in the European eel. Journal of Environmental Science and Health Part B, v. 34, n.1, p. 62-73, 1999.

14 FERNÁNDEZ-VEGA, C. et al. Thiobencarb-induced changes in acetylcholinesterase activity of the fish Anguilla anguilla. Pesticide Biochemistry and Physiology, v. 72, p. 55-63, 2002.

15 FONSECA, M.B. et al. The 2,4-D herbicide effects on acetylcholinesterase activity and metabolic parameters of piava freshwater fish (Leporinus obtusidens). Ecotoxicology and Environmental Safety, v. 69, p. $416-420,2008$.

16 GLUSCZAK, L. et al. Effect of glyphosate herbicide on acetylcholinesterase activity and metabolic and hematological parameters in piava (Leporinus obtusidens). Ecotoxicology and Environmental Safety, v. 65 , p. 237-241, 2006.

17 GOLOMBIESKI, J.I. et al. Qualidade da água no consórcio de peixes com arroz irrigado. Ciência Rural, v. 6 , n. 35, p. 1263-1268, 2005.

18 GOLOMBIESKI, J.I. et al. Efeitos do carbofurano, metsulfurom-metílico e azinsulfurom na sobrevivência de carpas e produção de arroz e peixes em rizipiscicultura. Pesticidas: r. ecotoxicol. e meio ambiente, v. 17, p. 59-66, 2007.

19 GOLOMBIESKI, J.I. et al. Acethylcholinesterase enzyme activity in carp brain and muscle after acute exposure to diafuran. Scientia Agricola, v. 65, p. 340-345, 2008.

20 MARCHEZAN, E. et al. Produção integrada de arroz e peixes. Ciência Rural, v. 36, n. 2, p. 411-417, 2006.

21 MIRON, D.S. et al. Lethal concentration of clomazone, metsulfuron methyl, and quinclorac for silver catfish, Rhamdia quelen, fingerlings. Ciência Rural, v. 34, n. 5, p. 1465-1469, 2004.

22 MIRON, D.S. et al. Effects of the herbicides clomazone, quinclorac, and metsulfuron methyl on acetylcholinesterase activity in the silver catfish (Rhamdia quelen) (Heptapteridae). Ecotoxicology and Environmental Safety, v. 61, p. 98-403, 2005.

23 MIRON, D.S. et al. Biochemical effects of clomazone herbicide on piavas (Leporinus obtusidens). Chemosphere, v. 74, p. 1-5, 2008.

24 MORAES, B.S. et al. Effects of four rice herbicides on some metabolic and toxicology parameters of teleost fish (Leporinus obtusidens). Chemosphere, v. 68, p. 1597-1601, 2007.

25 MORAES, B.S. et al. Toxicological responses of Cyprinus carpio after exposure to a commercial herbicide containing imazethapyr and imazapic. Ecotoxicology and Environmental Safety, 2009. (no prelo).

26 RESGALLA Jr. C. et al. Toxicidade aguda de herbicidas e inseticidas utilizados na cultura do arroz irrigado sobre juvenis de carpa (Cyprinus carpio). Pesticidas: r. ecotoxicologia e meio ambiente, v. 12, p. 59-68, 2002.

27 SAGLIO, P. et al. Behavior and olfactory responses to prochloraz, bentazone, and nicosulfuron contaminated flows in goldfish. Archives of Environmental Contamination and Toxicology, v. 41, n. 2, p. 192-200, 2001.

28 SAGLIO, P.; TRIJASSE, S. Behavior responses to atrazine and diuron in Goldfish. Archives of Environmental Contamination and Toxicology, v. 35, p. 484-491, 1998. 
29 SANCHO, E. et al. Liver energy metabolism of Anguilla anguilla, after exposure to feniltrothion. Ecotoxicology and Environmental Safety, v. 41, p. 168-175, 1998.

30 SATO, G. Rizipiscicultura: uma alternativa rentável para o produtor de arroz irrigado. Agropecuária Catarinense, v. 15, n. 3, p. 47-50, 2002.

31 SENSEMAN, S. (Ed.). Herbicide handbook. $9^{\text {th }}$ ed. Lawrence: The Weed Science Society of America, 2007. $458 \mathrm{p}$.

32 SOSBAI. Sociedade Sul-Brasileira de Arroz Irrigado. Arroz irrigado: recomendações técnicas da pesquisa para o Sul do Brasil. Santa Maria (RS), 2007. 159 p.

33 STRAUS, D. L.; CHAMBERS, J. E. Inhibition of acetylcholinesterase and aliesterases of fingerling channel catfish by chlorpyrifod, parathion, and S,S,S-tributyl phosphotrithioate (DEF). Aquatic Toxicology, v. 33, p. 311-324, 1995.

\section{ACKNOWEDGEMENTS}

The authors thank the UFSM, CNPq for the financial support. To CNPq for the fellowships granted to Dr. Golombieski and Agronomy Reimche. 